\title{
Population Structure and Fruit Productivity Analyses in Support of the Use of Caryocar brasiliense
}

\author{
Lorena Cristina Lana Pinto $^{1}$ (D), Irla Paula Stopa Rodrigues ${ }^{1}$ (D), \\ Maria Auxiliadora Drumond ${ }^{2}$
}

${ }^{1}$ Instituto Interdisciplinar de Estudos e Pesquisas em Sustentabilidade - INSTITUTO SUSTENTAR, Brumandinho, MG/Brasil

${ }^{2}$ Laboratório de Sistemas Socioecológicos, Instituto de Ciências Biológicas, Universidade Federal de Minas Gerais UFMG, Belo Horizonte, MG/Brasil

\begin{abstract}
The Brazilian Cerrado, a global biodiversity hotspot, has been widely converted by agricultural expansion and pasture establishment. As a result of these activities, several plant species have experienced population declines such as pequi (Caryocar brasiliense). We analyzed the feasibility of economic use of $C$. brasiliense based on population structure and fruit productivity. The average fruit production was high and significantly different between 2013 (515 fruits ind-1) and 2014 (344 fruits ind -1$)(t=2.32, p<0.01)$, with $33 \%$ less fruit production in 2014. The canopy area $(\mathrm{r} 2=0.22, \mathrm{p}<0.05)$ was the only population parameter related to productivity (2013). One hectare may yield an average of one ton of complete fruits, which is equivalent to up to 16 liters of pulp oil. The family income obtained with oil pulp sale could up to R $\$ 1,080$ (US\$ 327). We support the hypothesis that high pequi fruit productivity makes the extraction of this resource viable, especially for giant earthworm extractors.
\end{abstract}

Keywords: pequi, ecology, extractivism, rural community non-timber forest products. 


\section{INTRODUCTION}

The extraction of non-timber forest products (NTFPs), such as fruits, seeds, oils, resins, fibers, barks and aromatic, medicinal, and ornamental plants (Arnold \& Pérez, 2001; Soldati \& Albuquerque, 2008), has been proposed as a viable alternative to contain environmental degradation and improve the well-being of human communities (Arnold \& Pérez, 2001; Marshall \& Newton, 2003; Schreckenberg et al., 2002). The gathering and commercialization of NTFPs ensures the food security of a large portion of the human population and generates opportunities for low-income communities (Belcher \& Schreckenberg, 2007; Homma, 2010). For example, many families in the Brazilian Amazon earn a large portion of their family income from the commercialization of the Brazil nut (Bertholletia excelsa), açaí (Euterpe oleracea), and cupuaçu (Theobroma grandiflorum). These NTFPs have significant value and appreciation in national and international markets (Peres et al., 2003; Homma, 2010).

Tropical savannas host over half of the world's population residing in African, Asian and South American countries, and these peoples are strongly dependent on NTFPs. The Cerrado is the most diverse tropical savanna in the world and covers approximately two million $\mathrm{km}^{2}$ in central Brazil (Ratter et al., 1997; Klink \& Machado, 2005). This biome is a biodiversity hotspot (Mittermeier et al., 2004). Despite its biological and cultural richness resulting from the existence of traditional communities, such as natives, quilombolas and artisanal fishermen (Diegues, 2000), a large part of its vegetation remnants are being replaced by monocultures and pastures, usually aided by public economic expansion policies (Zardo \& Henriques, 2011; Giroldo \& Scariot, 2015).

The Cerrado has over 50 plant species that are used for food, medicinal and economic purposes with established national and international markets (Felfili et al., 2004; Afonso \& Ângelo, 2009). Native species with relevant economic potential include the araticum (Annona crassiflora), cagaita (Eugenia dysenterica), baru (Dipteryx alata), and pequi (Caryocar brasiliense) (Pozo, 1997; Afonso \& Ângelo, 2009). A study on the production rates of NTFPs in Brazil showed that only the production of copaiba oil and pequi oil increased between 1982 and 2005 (Afonso \& Ângelo, 2009). Thus, the pequi is the main Cerrado product commercialized in large amounts, as most of the copaiba oil supply comes from the Amazon region.

The national market demand for pequi increased from 3300 tons in 2001 to 5700 tons in 2010 (Young et al., 2012). The increasing demand for this and other NTFPs associated with environmental impacts and the economic difficulties faced by rural communities may contribute to its unrestrained harvest, thereby altering its survival, growth and reproduction rates, with subsequent changes in fruiting events and the proportion of seedlings, juveniles and adults (Giroldo \& Scariot, 2015)

The structure of a managed population may indicate its conservation state. Additionally, the factors that may affect a species' productivity can be better understood when fruit production is associated with the species' demographic parameters, thereby allowing the establishment of management strategies that do not affect long-term species persistence (Leite et al., 2006; Zardo \& Henriques, 2011; Virillo et al., 2011). Studies of $C$. brasiliense extraction in yet unmanaged Cerrado areas enable us to assess other factors that may affect the population structure and productivity of this species (Giroldo \& Scariot, 2015), and consequently to propose conservation measures considering the current scenario and extraction as an income source.

The aim of this study was to analyze the population structure and productivity of $C$. brasiliense in a Cerrado area within a quilombola territory to gather evidence on the use of this NTFP as an alternative income source allied to this biome conservation. We considered the following hypothesis in this study: the C. brasiliense productivity and fruit yield enable its use as an alternative income source.

\section{MATERIAL AND METHODS}

\subsection{Study area and species}

This study was conducted in a Cerrado area within the territory of a quilombola remnant called the Pontinha Quilombola Community $\left(19^{\circ} 23^{\prime} 07.3^{\prime \prime} \mathrm{S}\right.$ and $44^{\circ} 27^{\prime} 21.3^{\prime \prime}$ W, Decree n ${ }^{\circ} 4,887$ of November 20 , 2003) in the municipality of Paraopeba, located in the central region of Minas Gerais state (Figure 1). In Brazil, the lands occupied by the quilombola community 
remnants are protected areas, which are considered “[...] natural and semi-natural environments defined geographically, regulated, administered and/or managed for biodiversity conservation and sustainable use [...]" (Brasil, 2006, p. 38).
This territory has a predominance of Cerrado trees and shrubs that have been converted into pastures and monocultures. The altitude in the region varies from 734 to $750 \mathrm{~m}$, and the climate is humid subtropical with rainy summers and dry winters (Cwa) according

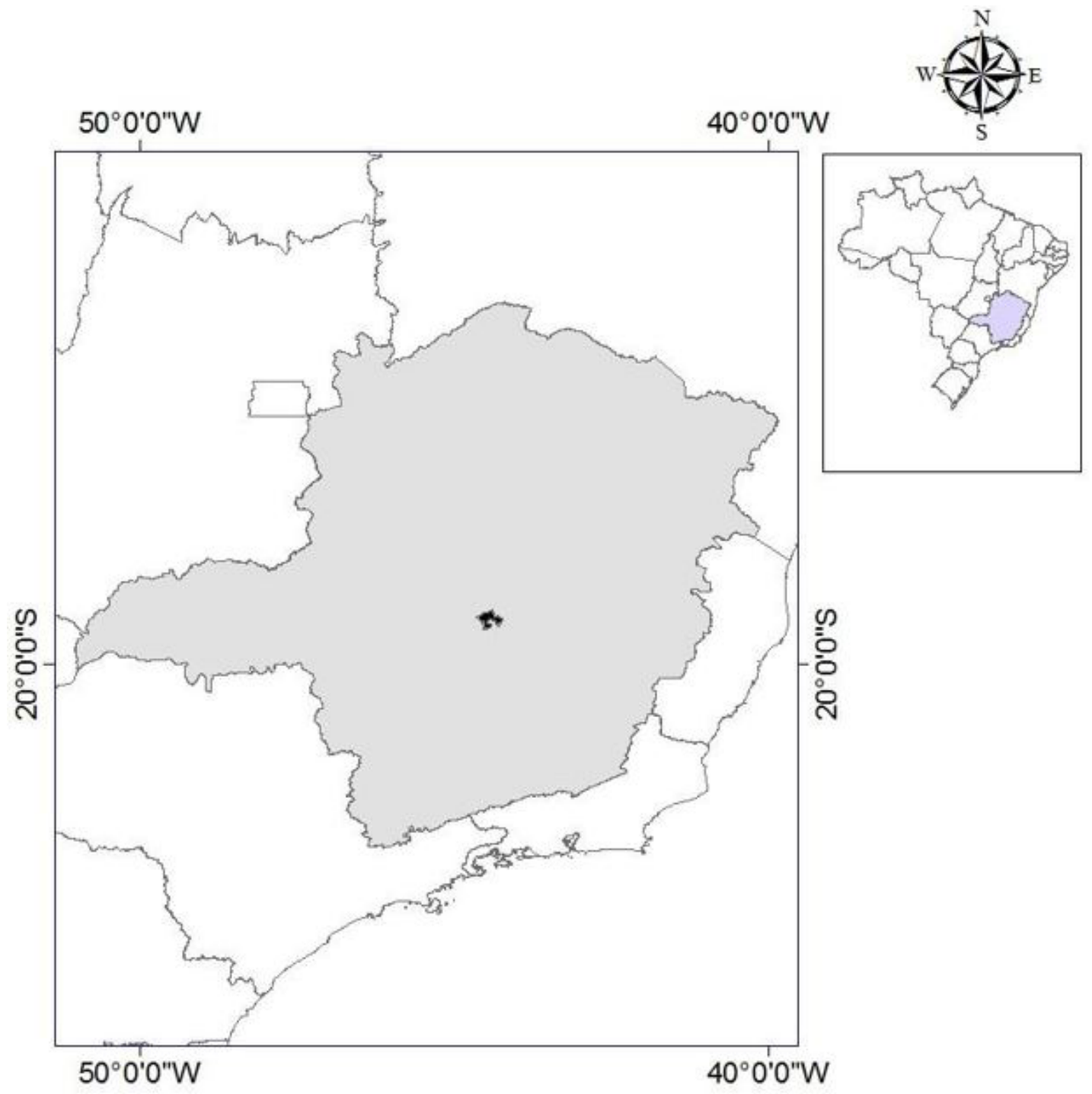

\section{$\begin{array}{lllll}0 & 100200 & 400 & 600 & 800\end{array}$ \\ Kilometers}

Coordinate System: GCS South American 1969 Datum: South American 1969

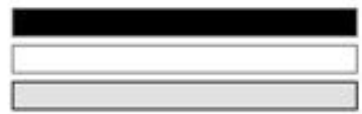

Figure 1. Paraopeba Municipality, central region of Minas Gerais state, southeastern Brazil, where the territory of Pontinha community is located (Pinto et al., 2016). 
to the Köppen climate classification. The mean annual temperature is $21^{\circ} \mathrm{C}$, and the total annual rainfall varies from 1300 to $1600 \mathrm{~mm}$, with a monthly mean under $40 \mathrm{~mm}$ during the dry season (Alvares et al., 2014).

The territory of this community still has no official demarcation. Thus, the community members define the areas of occupation and land use. The community is composed of approximately 200 family units whose main income source is the extraction of a giant earthworm (minhocuçu) endemic to the Cerrado (Rhinodrilus alatus) that has been sold as live bait for over 80 years in the region. Informal agreements with extractivists and merchants led to the suspension of the extraction of $R$. alatus during its reproductive period (Drumond et al., 2015). Because the pequi tree C. brasiliense (Caryocaraceae) occurs in this territory and produces fruits during the same period, its fruits have been indicated by the community as a potential NTFP for use as an alternative source of income (Pinto et al., 2016).

The pequi is a tree species endemic to the Cerrado that is also found in transition zones within the Amazon Forest, the Caatinga, and the Pantanal (Araújo, 1995). Flowering mostly occurs from July to September and fruiting from October to March (Leite et al., 2006).

The pequi fruit is a drupe that has approximately 12 centimeters in diameter with an average weight of 100 grams, and can contain one to four pyrenes (known popularly as caroços). The pyrene is the dispersal unit and is composed of the stiff and spiny endocarp and the internal mesocarp or pulp. The pulp has high nutritional value and is rich in carotenoids, vitamins A and C, flavonoids, tannins, and oils (Almeida, 2008). The fruits are used in many parts of Brazil in traditional sweet and savory dishes, condiments, oils, and liqueurs (Rezende \& Cândido, 2014).

\subsection{Population structure and fruit production}

For C. brasiliense sampling, we first prepared a map with the current use area of the territory with the participation of community members. In December and January 2013, we defined the territory's limits and created a shapefile of the territory in Quantum GIS (QGIS Development Team, 2016) and Google Earth. We estimated the use area as 1,184 hectares, 1,030 hectares of which corresponded to the area with potential pequi occurrence. We did not consider the 154 remaining hectares corresponding to the territory occupied by farmers, squatters and reforestation of a steel company or to areas where C. brasiliense did not occur, such as wetlands, riparian vegetation, and water bodies as use areas (Sano et al., 2008). The C. brasiliense density was assessed by randomly sampling $6020 \times 50 \mathrm{~m}$ plots for a total sampling area of 6 hectares between the years of 2013 and 2014 (Figure 2).

In each plot, we marked all C. brasiliense individuals and measured the stem diameter at ground level (DGL), diameter at breast height $(\mathrm{DBH}, 1.30 \mathrm{~cm})$, total height $(\mathrm{TH})$, and canopy projection area (CPA). These measurements were taken using a measuring tape, a digital caliper and a telescopic rod. Stems bifurcating at soil level were considered to belong to different individuals if they were $30 \mathrm{~cm}$ apart or more at soil level. We defined individual classes based on their DGL, DBH, and TH values and on fruit presence or absence. With the exception of resprouting (cut down) individuals, individual trees were considered infants with a height $\leq 1.30 \mathrm{~cm}$ and $\mathrm{DGL} \leq 3.5 \mathrm{~cm}$. Trees with a DGL $>3.5 \mathrm{~cm}$ and $\mathrm{DBH}<10 \mathrm{~cm}$ that could not reproduce were considered juveniles, and trees that were reproductive with a $\mathrm{DBH} \geq 0 \mathrm{~cm}$ were considered adults. We recorded fruiting and flowering as a binary presence/absence variable, with the number one (1) representing reproductive individuals and the number zero (0) representing non-reproductive individuals.

For the physical characterization of fruits in 2013 and 2014, we randomly selected ten adult pequi trees and collected ten healthy fruits from each individual. Using a precision scale, we measured the total weight of each fruit, the weight and number of the pyrenes and the weight of the pulp, which was extracted from the pyrenes with a knife. We assessed whether differences existed in the fruits' physical variables between the years using the t-test $(\alpha=0.05)$ (PAST, version 2.17).

In all plots, we identified possible threats to the C. brasiliense populations, including the following: i) giant earthworm extraction (which leads to seedling removal during soil disturbance); ii) conversion of Cerrado areas into pastures; iii) pequi tree logging; iv) fire; v) Eucalyptus and Pinus monocultures; and vi) family agriculture. These activities were recorded 

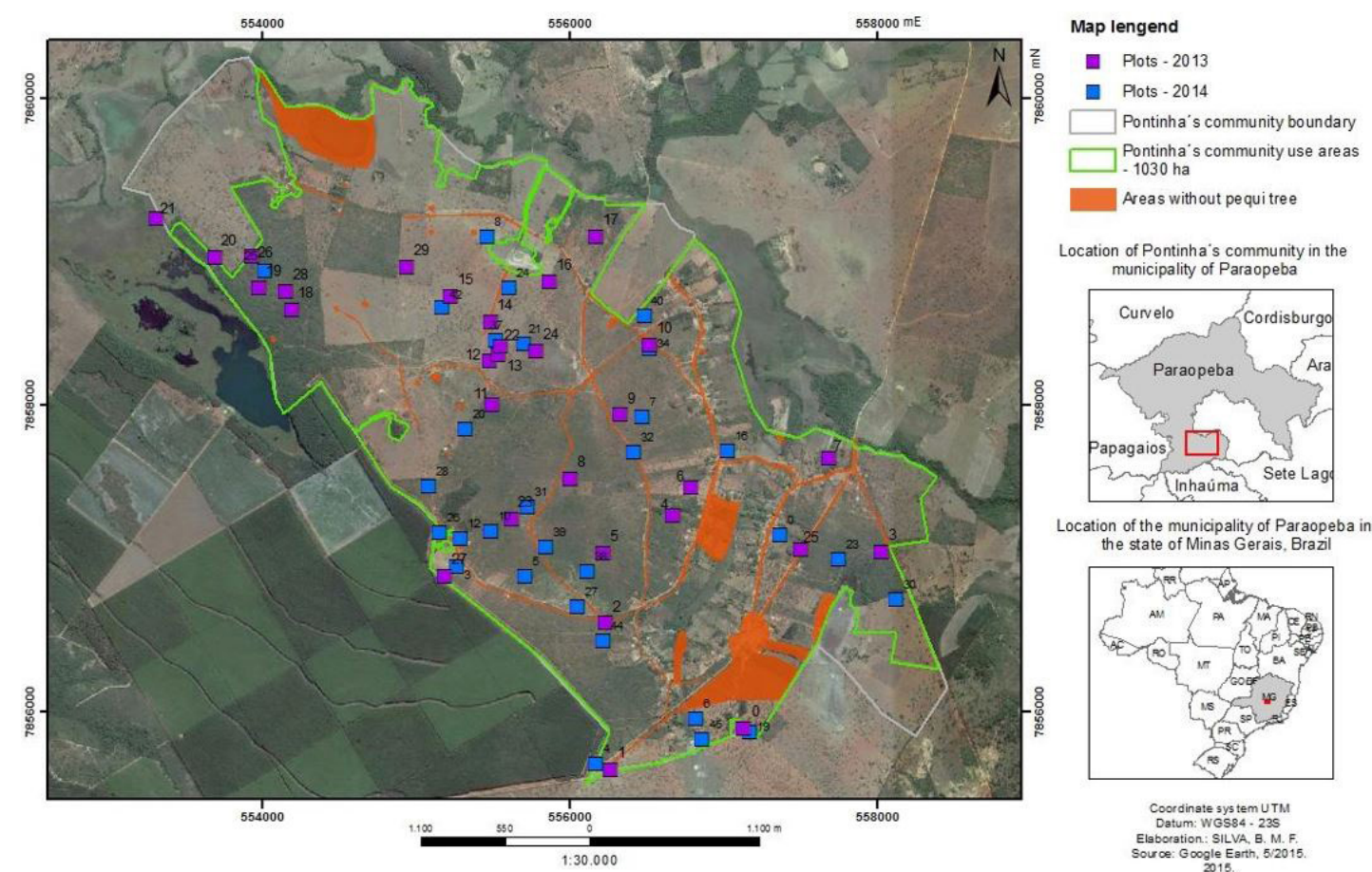

Figure 2. Geographic limits of the quilombola territory. The blue and purple squares correspond to the plots, and the orange squares correspond to the community areas where Caryocar brasiliense does not occur.

as present (1) or absent (0) in each plot, and analyzed quantitatively by their frequencies of occurrence.

Considering the low accuracy in determining C. brasiliense fruit production by conventional means, such as visual estimates and random branch sampling (Santana \& Naves, 2003; Borges et al., 2012), we used a participative fruit counting method. Twenty-four community members monitored 24 adult pequi trees during two consequent harvests (2013 and 2014 years). Each participant counted and recorded on a calendar the number of fruits fallen from a C. brasiliense individual. The individuals of $C$. brasiliense monitored by the community members were located in Cerrado areas near their homes. To calculate productivity, we estimated production per area by multiplying the number of adult individuals in a hectare by the average fruit production quantified by the community members.

We used the t-test (PAST, version 2.17) to compare productivity between the two years and to predict fruit production of the 24 pequi trees in 2013 and 2014 based on their DBH, TH, and CPA values. We performed a multiple regression analysis (stepwise at $\alpha=0.05$ ) using Generalized Linear Models (GLMs) (R, version 3.3.1).

\section{RESULTS}

\subsection{Population structure}

In 2013 and 2014 we sampled 342 pequi trees in six hectares $\left(57\right.$ ind $\left.\mathrm{ha}^{-1}\right)$ with the following mean parameters: $\mathrm{DBH}=13.44 \mathrm{~cm}, \mathrm{DGL}=19.27 \mathrm{~cm}$, $\mathrm{CPA}=17.67 \mathrm{~m}^{2}$, and $\mathrm{TH}=3.62 \mathrm{~m}$ (Table 1$)$.

The distribution of individuals per class was 40 infants ( 7 plants ha $\left.{ }^{-1}\right), 63$ juveniles ( 11 plants ha $\left.{ }^{-1}\right)$, 117 adults ( 19 plants ha $^{-1}$ ), and 122 resprouts (20 plants ha $^{-1}$ ) (Figure 3a). To assess the classes to which the resprouts would belong if their growth had not been interrupted, we reclassified these individuals based on their DGLs, resulting in a total of 168 adults and 105 juveniles (Figure 3b). Thirty-nine pequi trees could not be reclassified because their DGLs could not be measured.

Of the possible threats to the C. brasiliense populations, the logging of pequi trees was the most frequent activity in the sampled plots $(50 \% ; \mathrm{n}=30)$. This threat was identified through clues left in place, such as fallen branches of the cut tree. Other major 
Table 1. Population characteristics of Caryocar brasiliense in six hectares ( $\mathrm{n}=342)$ sampled in 2013 and 2014 in the Pontinha quilombola territory, Minas Gerais, Brazil.

\begin{tabular}{lccc}
\multicolumn{1}{c}{ Parameter } & Minimum & Maximum & Average $( \pm$ sd) \\
Diameter at ground level (DGL) & $0.13 \mathrm{~cm}$ & $74.08 \mathrm{~cm}$ & $19.27 \pm 15.83 \mathrm{~cm}$ \\
Diameter at breast height (DBH, $1.30 \mathrm{~cm})$ & $1.27 \mathrm{~cm}$ & $62.07 \mathrm{~cm}$ & $13.44 \pm 11.38 \mathrm{~cm}$ \\
Canopy projection area (CPA) & $0.1 \mathrm{~m}^{2}$ & $320.91 \mathrm{~m}^{2}$ & $17.67 \pm 15.83 \mathrm{~m}^{2}$ \\
Total height $(\mathrm{TH})$ & $0.1 \mathrm{~m}$ & $9.0 \mathrm{~m}$ & $3.62 \pm 2.77 \mathrm{~m}$ \\
\hline
\end{tabular}
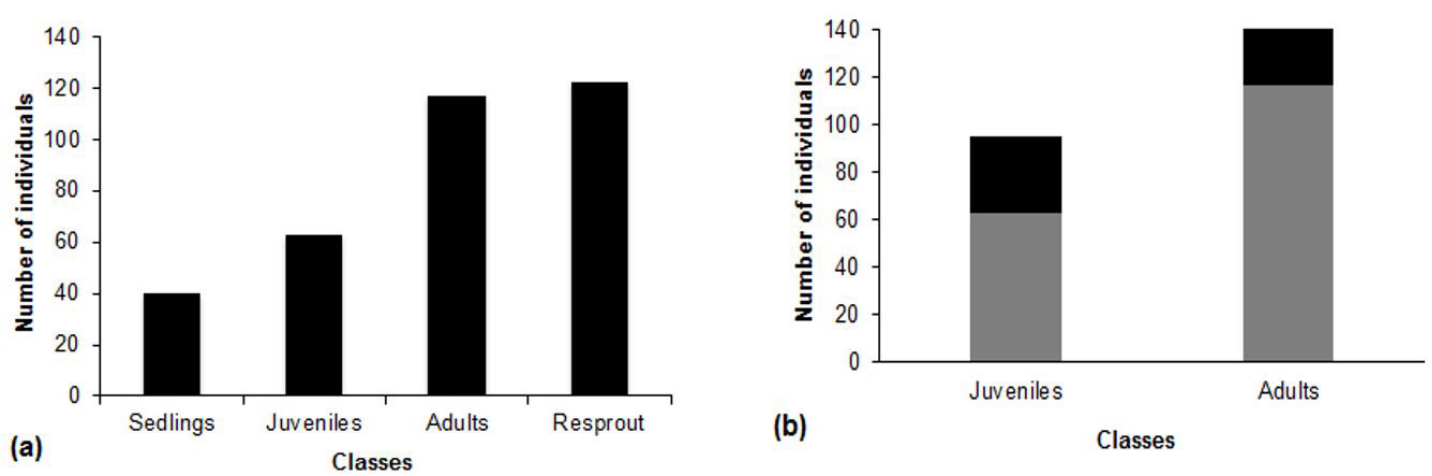

Figure 3. (a) Distribution of Caryocar brasiliense individuals in the six sampled hectares $(\mathrm{n}=342)$ in a quilombola territory, Paraopeba, Minas Gerais. Infant (height $\leq 1.30 \mathrm{~cm}$ and DGL $\leq 3.5 \mathrm{~cm}$ ), juvenile (DGL $>3.5 \mathrm{~cm}$ and $\mathrm{DBH}<10.0 \mathrm{~cm})$, adult $(\mathrm{DBH} \geq 10.0 \mathrm{~cm}$ ) and resprouts; (b) Classification of resprouts (Figure 3a) into juveniles and adults (black bar) according to their DGL values summed to the other individuals of these classes (gray bar).

threats are giant earthworm extraction $(37 \% ; n=22)$, pasture establishment $(33 \% ; \mathrm{n}=20)$, fire $(25 \% ; \mathrm{n}=15)$, monocultures $(16 \% ; \mathrm{n}=10)$, and family agriculture $(1.6 \% ; \mathrm{n}=1)$.

\subsection{Productivity}

The 24 monitored pequi trees produced a total of 12,355 fruits in 2013 (min. 25, max. 1866, mean $515 \pm 380$ ) and 8,261 fruits in 2014 (min. 1, max. 1,669 , mean $344 \pm 404$ ), with the production in 2014 being significantly different $(\mathrm{t}=2.32, \mathrm{p}<0.05)$ and $33 \%$ smaller than in 2013 (Figure 4).

Fruit production by the monitored individuals was positively related to the canopy area in 2013 $\left(\mathrm{r}^{2}=0.22, \mathrm{p}<0.05\right)$ (Figure 5). However, in 2014, no significant relationship ( $\mathrm{p}>0.05$ ) was observed between productivity and the population parameters $\mathrm{DBH}, \mathrm{CPA}$, and $\mathrm{TH}$.

The fruit, pyrene and pulp weight did not significantly differ between 2013 and 2014 ( $\mathrm{p}>0.05$ ). However, the number of pyrenes per fruit was significantly different between the two years $(t=2.59, \mathrm{p}<0.05)$
(Table 2). We estimated the average fruit production per hectare to be $9,785\left(1,498 \mathrm{~kg} \mathrm{ha}^{-1}\right)$ in 2013 and 6,536 $\left(1,000 \mathrm{~kg} \mathrm{ha}^{-1}\right)$ in 2014 . The pyrene yield was estimated to be $369.8 \mathrm{~kg} \mathrm{ha}^{-1}$ in 2013 and $224.3 \mathrm{~kg} \mathrm{ha}^{-1}$ in 2014 , and the pulp yield was estimated to be $98 \mathrm{~kg} \mathrm{ha}^{-1}$ in 2013 and $73 \mathrm{~kg} \mathrm{ha}^{-1}$ in 2014.

\section{DISCUSSION}

Our data show that the use of pequi can provide an alternative source of work and income for the quilombo community of Pontinha, although the density of plants (57 plants ha ${ }^{-1}$ ) in the study area is lower than in other areas of Brazil, such as in the Central-West Region (Santana \& Naves, 2003; Zardo \& Henriques, 2011) and in northern Minas Gerais (Oliveira \& Scariot, 2010). The potential of using pequi is supported by data regarding the number and weight of fruits and pyrenes, and the production of fruits, which is much higher in the study area than in areas with or without extractive activities in other regions of the country. These regional differences are likely related to several 
Table 2. Physical characterization of Caryocar brasiliense fruits in 2013 and $2014(\mathrm{n}=98)$.

\begin{tabular}{|c|c|c|c|c|c|}
\hline Variable & $\operatorname{Min}-\operatorname{Max}^{*}$ & $\begin{array}{c}\text { Mean } \\
( \pm \text { sd) }(2013)\end{array}$ & $\begin{array}{c}\text { Mean } \\
( \pm \text { sd) }(2014)\end{array}$ & $\begin{array}{c}\text { Mean } \\
(2013 / 2014)\end{array}$ & $p$ value ${ }^{\star *}$ \\
\hline Fruit weight & $44-366 \mathrm{~g}$ & $160.6 \pm 61.6 \mathrm{~g}$ & $146.2 \pm 44.4 \mathrm{~g}$ & $153.1 \pm 9.75 \mathrm{~g}$ & 0.2 \\
\hline Pyrene weight & $15-46 \mathrm{~g}$ & $27.0 \pm 6.1 \mathrm{~g}$ & $28.6 \pm 6.6 \mathrm{~g}$ & $27.8 \pm 1.1 \mathrm{~g}$ & 0.1 \\
\hline Pulp weight & $5-18 \mathrm{~g}$ & $7.7 \pm 2.3 \mathrm{~g}$ & $8.6 \pm 2.3 \mathrm{~g}$ & $8.1 \pm 0.6 \mathrm{~g}$ & 0.5 \\
\hline Number of pyrenes & $1-3$ & $1.4 \pm 0.6$ & $1.2 \pm 0.4$ & $1.3 \pm 0.1$ & 0.01 \\
\hline
\end{tabular}

Values representing the smallest and largest fruits, pyrene and pulp weights, and the number of pyrenes per fruit*; Significance level of $5 \%^{* *}$.

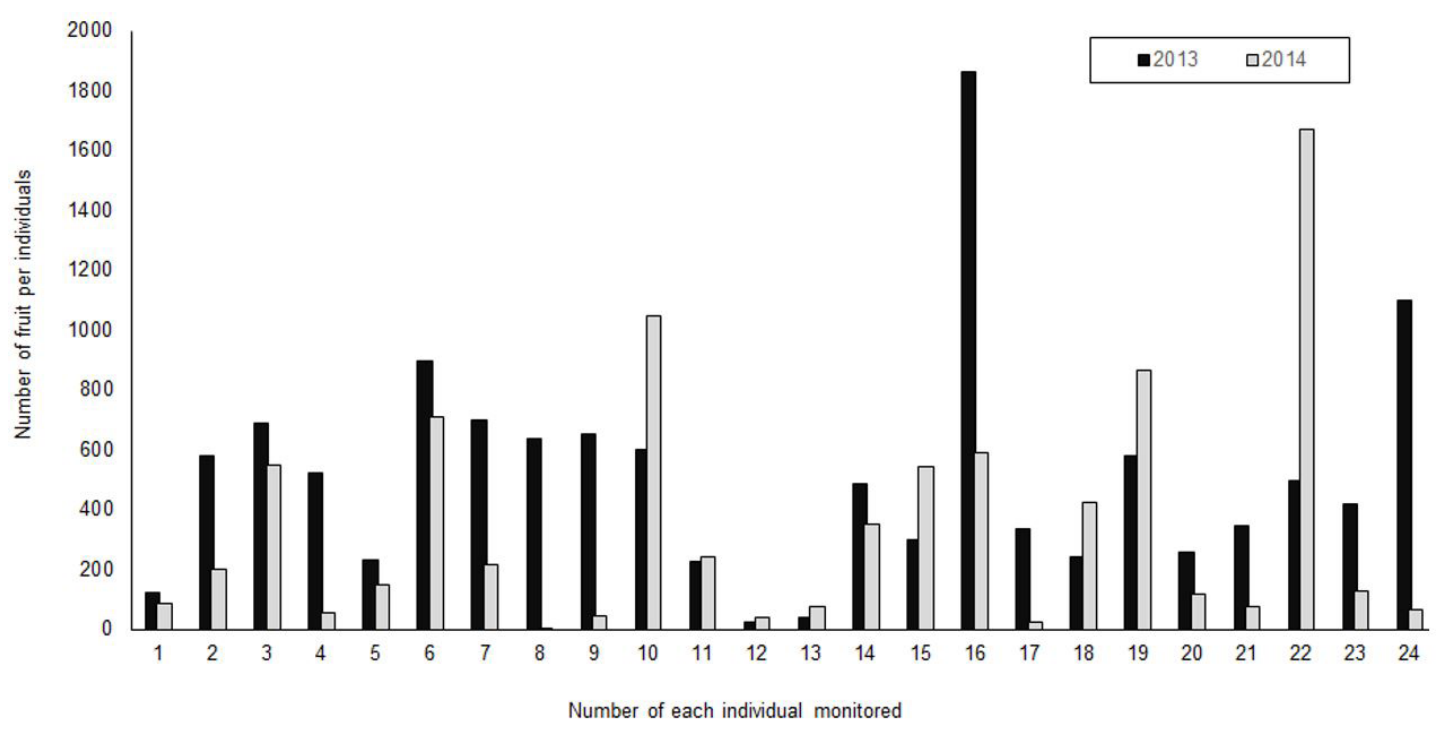

Figure 4. Total number of fruits produced by each C. brasiliense individual $(\mathrm{n}=24)$ monitored in 2013 and 2014.

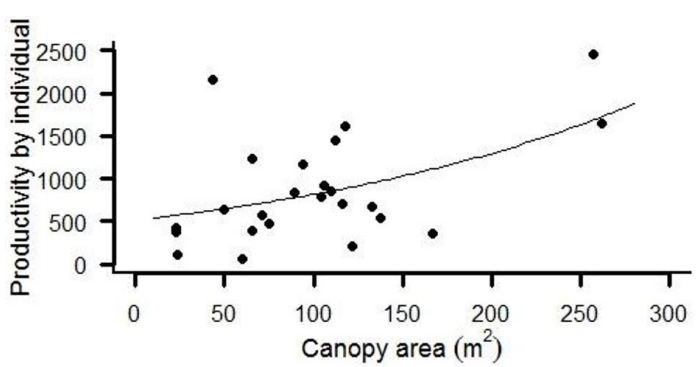

Figure 5. Number of fruits per canopy area for Caryocar brasiliense in a quilombola territory, Paraopeba, Minas Gerais state, Brazil. Regression equation for 2013 year $y=6.2422+0.0046 \mathrm{x}\left(\mathrm{F}_{1.22}=7.367\right.$, $\mathrm{p}<0.05)$.

factors, including microclimatic conditions, soil quality, plant density, pollinator abundance, and human intervention; however, they may also be due to different methods of data collection (Zardo \& Henriques, 2011; Ferreira et al., 2015).
Canopy area was the only population parameter significantly related to fruit production, as has been observed in other studies in northern Minas Gerais and Goiás (Oliveira \& Scariot, 2010; Ferreira et al., 2015). Individuals with larger canopies have more resources, which can favor greater fruit production (Oliveira \& Scariot, 2010). However, only $22 \%$ of productivity can be explained by canopy area, indicating that other factors, such as annual rainfall, could influence fructification, as documented by Leite et al. (2006) in the northern region of Minas Gerais.

The participation of community members in fruit counts from the number of fallen fruits, as in the present study, may reduce errors of under or overestimation. Additionally, this approach favors greater involvement of community in the study, which we considered important because it establishes bonds between external and local researchers from the beginning, and provides grounds for participative 
governance in the future management of this resource (Williams, 2011). Fruit counts made by communities that use a resource have been incorporated in other studies, such as the participatory monitoring of Amla (Phyllanthus indofischeri and P. emblica) extraction, an important NTFP for indigenous communities of southern India (Sinha \& Bawa, 2002).

Based on the production potential and density of $C$. brasiliense in the studied quilombola territory, one hectare may yield an average of 1 ton of complete fruits, which is equivalent to up to 16 liters of pulp oil, the production of which requires approximately 400 pyrenes. This byproduct has a high market value of up to R \$ 30 per liter (US\$ 9) (Pinto et al., in preparation), and is used mostly in the cosmetic and pharmaceutical industries (Pianovski et al., 2008; Enes et al., 2011). In two work days, a farmer can extract up to 3 liters of oil, which translates to a monthly family income of up to R\$1,080 (US\$ 327) only with this product.

Although extractivism of NTFPs has positive effects for the conservation of species due to their valorization, it can also have negative effects on populations, such as overexploitation (Peres et al., 2003; Ticktin, 2004), especially when done commercially. However, the greatest threat may not be from the gathering of fruits, leaves, seeds or other plant parts, but other factors such as logging and deforestation. In the community of Sierra de Manantlán, in Mexico, intensive logging of tila (Ternstroemia lineata) and blackberry (Rubus sp.) is reported to be the main threat to the extraction of these resources, some of the main sources of income for women there (Marshall \& Newton, 2003). This threat has also been observed in areas with intensive extractivism of baobab fruit (Adansonia digitata) for mukua in Mali, Africa (Dhillion \& Gustad, 2004).

In the present study, the main threat to C. brasiliense was the cutting of trees, but impacts resulting from the extraction of the giant earthworm minhocuçus (Rhinodrilus alutus), with the inversion of soil and the removal of the herbaceous stratum and the seed bank, are also important. In pasture areas, primarily occupied by landowners who exploit lands within the quilombo territory, adult pequi trees are predominant, but the renewal and establishment of young trees is rare due to grazing, tilling, and burning for pasture clearance. Even in areas of Cerrado, the presence of cattle is frequent and can damage this species because cattle compromise plant development, especially of young plants, by the consumption of branches and leaves (Ferreira et al., 2015). Although less frequent than other threats in the study area, fire is traditionally used to "clear" pastures and other agricultural areas, and for collecting giant earthworms (Drumond et al., 2013). Pequi trees with a height equal to or below the grass-herb stratum, such as seedlings and juveniles, are at a greater risk of injury and mortality during such fire events (Medeiros \& Miranda, 2005), which may compromise the population in the long term.

Extraction and sale of giant earthworms are important to the families in the quilombola territory, yet there is a need for an alternative income source, especially during the reproductive period of the worms. For comparison, up to 13 dozen giant earthworms can be extracted from one hectare of Cerrado, which are sold for R\$20-30 (US\$ 6.50-9.00). An extractivist working five days per week and collecting on average 1.5 to 3 dozen giant earthworms per day may earn between R\$ 600 and 1,800 (US\$ 181 and 545) per month (Silva et al., in preparation). Due to annual variation in giant earthworm availability, and the demand for live fishing bait for which the worms are used, income earned from this activity is unstable (Silva et al., in preparation). Pequi extraction and processing would enable a rural worker to consistently earn a monthly income equal to or greater than the income earned from giant earthworm extraction.

Additionally, climate change (IPCC, 2014) is leading to significant changes in species distributions, and models predict a severe reduction in the distribution of $R$. alatus over the next 70 years (Hughes et al., unpublished data). The distribution and availability of $C$. brasiliense will also be affected by these changes due to the probable decrease in areas of Cerrado and, consequently, pequi trees, by 2050 (Nabout et al., 2011). Brazilian states that currently supply the pequi market, such as Goiás and Minas Gerais, will experience negative impacts associated with the unavailability of the fruit in the long-term. The region studied will be one of the few Cerrado remnants with a high probability for the occurrence of C. brasiliense in the future (Nabout et al., 2011), reinforcing its importance for the conservation of this species for the generation of local income and the maintenance of the pequi production chain. 


\section{CONCLUSION}

The present study provides evidence of the viability of using pequi as an alternative source of income for quilombolas, especially those depending on giant earthworm extraction. In addition to extractivism, the processing and commercialization of the fruit of pequi could provide an incentive for native residents to valorize the Cerrado biome and its exploited species. The data gathered in this study support the development of management practices based on community participation and the uncertainties and complexities of natural resource dynamics.

\section{ACKNOWLEDGEMENTS}

We thank the Pró-Reitorias de Extensão (ProEx) and Pesquisa (PRPq) from Universidade Federal de Minas Gerais and Programa de Pós Graduação em Ecologia, Conservação e Manejo da Vida Silvestre. We are also grateful to the Programa de Extensão Universitária do Ministério da Educação (PROEXT MEC-2013 and 2015), Fundação de Amparo à Pesquisa de Minas Gerais and Floresta Nacional de Paraopeba for logistical support.

\section{SUBMISSION STATUS}

Received: 4 oct., 2017

Accepted: 25 may, 2018

\section{CORRESPONDENCE TO}

\section{Lorena Cristina Lana Pinto}

Instituto Interdisciplinar de Estudos e

Pesquisas em Sustentabilidade - INSTITUTO

SUSTENTAR, Av. Hum, 2863, Casa Branca,

CEP 35460-000, Brumadinho, MG, Brasil

e-mail: lorena_clp@yahoo.com.br

\section{FINANCIAL SUPPORT}

Fundação de Amparo à Pesquisa do Estado de Minas Gerais (FAPEMIG/APQ-02423-12). Programa de Extensão Universitária do Ministério de Educação (Proext)/Pró-Reitoria de Pesquisa, Universidade Federal de Minas Gerais PROEXT-MEC/23072011340/2013-41 (2013) and 23072026414/2015-13 (2015).

\section{REFERENCES}

Afonso SR, Ângelo H. Market of non-wood forest products from brazilian savanna. Ciência Florestal 2009; 19(3): 315-332.

Almeida SP. Frutas nativas do Cerrado: caracterização físico-química e fonte potencial de nutrientes. In: Sano SM, Almeida SP, Ribeiro JF, editores. Cerrado ecologia e flora. Brasília: Embrapa Cerrados; 2008.

Alvares CA, Stape JL, Sentelhas PC, Gonçalves JLM, Sparovek G. Köppen's climate classification map for Brazil. Meteorologische Zeitschrift 2014; 22(6): 711-728. http:// dx.doi.org/10.1127/0941-2948/2013/0507.

Araújo FD. A review of Caryocar brasiliense (Caryocaraceae): An economically valuable species of the Central Brazilian Cerrado. Economic Botany 1995; 49(1): 40-48. http:// dx.doi.org/10.1007/BF02862276.

Arnold JEM, Pérez MR. Can non-timber forest products match tropical forest conservation and development objectives? Ecological Economics 2001; 39(3): 437-447. http://dx.doi.org/10.1016/S0921-8009(01)00236-1.

Belcher SK, Schreckenberg K. Commercialisation of non-timber forest products: a reality check. Development Policy Review 2007; 25(3): 355-377. http://dx.doi. org/10.1111/j.1467-7679.2007.00374.x.

Borges LM, Rezende AV, Nogueira GS. Avaliação da amostragem aleatória de ramos para quantificar a produção de frutos de Caryocar brasiliense Camb. (Caryocaraceae). Ciência Florestal 2012; 22(1): 113-124. http://dx.doi. org/10.5902/198050985084.

Brasil. Ministério do Meio Ambiente - MMA. Plano Nacional de Áreas Protegidas (PNAP). Brasília: Secretaria de Biodiversidade e Florestas, Diretoria de Áreas Protegidas; 2006.

Dhillion SS, Gustad G. Local management practices influence the viability of the baobab (Adansonia digitata Linn.) in different land use types, Cinzana, Mali. Agriculture, Ecosystems \& Environment 2004; 101(1): 85-103. http:// dx.doi.org/10.1016/S0167-8809(03)00170-1.

Diegues AC. Etnoconservação da natureza: enfoques alternativos. In: Diegues AC, organizadores. Etnoconservação: novos rumos para a proteção da natureza nos trópicos. 2. ed. São Paulo: NUPAUB; USP; 2000.

Drumond MA, Guimarães AQ, El Bizri HR, Giovanetti LC, Sepúlveda DG, Martins RP. Life history, distribution and abundance of the giant earthworm Rhinodrilus alatus RIGHI 1971: conservation and management implications. Brazilian Journal of Biology = Revista Brasileira de Biologia 2013; 73(4): 699-708. http://dx.doi.org/10.1590/S151969842013000400004. PMid:24789384.

Drumond MA, Guimarães AQ, Silva RRP. The role of local knowledge and traditional extraction practices in the management of giant Earthworms in Brazil. PLoS 
One 2015; 10(4): 4. http://dx.doi.org/10.1371/journal. pone.0123913. PMid:25874618.

Enes BN, Cardoso LDM, Castro PMD, Cesário CDC, Sant'Ana HM, Moreira AVB et al. Pequi (Caryocar brasiliense Camb.): perfil de carotenóides, vitaminas e atividade antioxidante. Nutrire 2011; 36: 17.

Felfili JM, Silva-Júnior MC, Sevilha AC, Fagg CW, Walter BMT, Nogueira PE et al. Diversity, floristic and structural patterns of cerrado vegetation in Central Brazil. Plant Ecology 2004; 175(1): 37-46. http://dx.doi. org/10.1023/B:VEGE.0000048090.07022.02.

Ferreira GA, Naves RV, Chaves LJ, Veloso VR, Souza ERB. Production of fruits from natural populations of pequi trees in the state of Goiás, Brazil. Revista Brasileira de Fruticultura 2015; 37(1): 121-129. http://dx.doi. org/10.1590/0100-2945-404/13.

Giroldo AB, Scariot AO. Land use and management affects the demography and conservation of an intensively harvested Cerrado fruit tree species. Biological Conservation 2015; 191 : 150-158. http://dx.doi.org/10.1016/j.biocon.2015.06.020.

Homma AKO. O crescimento do mercado como mecanismo de desagregação da economia extrativa. In: Silva VA, Almeida ALS, Albuquerque UP, organizadores. Etnobiologia e etnoecologia: pessoas \& natureza na América Latina. Recife: NUPEEA; 2010.

Intergovernmental Panel on Climate Change - IPCC. Climate Change. Impacts, Adaptation, and Vulnerability. Part A: Global and Sectoral Aspects. Contribution of Working Group II to the Fifth Assessment Report of the Intergovernamental Panel on Climate Chage. Cambridge: IPCC; 2014.

Klink CA, Machado RB. Conservation of the Brazilian Cerrado. Conservation Biology 2005; 19(3): 707-713. http:// dx.doi.org/10.1111/j.1523-1739.2005.00702.x.

Leite GLD, Veloso RVDS, Zanuncio JC, Fernanda LA, Almeida CIM. Phenology of Caryocar brasiliense in Brazilian Cerrado region. Forest Ecology and Management 2006; 236(2-3): 286-294. http://dx.doi.org/10.1016/j. foreco.2006.09.013.

Marshall E, Newton AC. Non-timber forest products in the community of El Terrero, Sierra de Manantlán Biosphere Reserve, Mexico: is their use sustainable. Economic Botany 2003; 57(2): 262-278. http://dx.doi.org/10.1663/00130001(2003)057[0262:NFPITC]2.0.CO;2.

Medeiros MB, Miranda HS. Mortalidade pós-fogo em espécies lenhosas de campo sujo submetido a três queimadas prescritas anuais. Acta Botanica Brasílica 2005; 19(3): 493-500. http://dx.doi.org/10.1590/S010233062005000300009.

Mittermeier RA, Gil PR, Hoffman M, Pilgrim J, Brooks T, Mittermeier CG, et al. Hotspots revisited. Mexico: Cemex; 2004.
Nabout JC, Oliveira G, Magalhães MR, Carina TL, Almeida FAS. Global climate change and the production of "Pequi" fruits (Caryocar brasiliense) in the Brazilian Cerrado. Natureza \& Conservação 2011; 9(1): 55-60. http://dx.doi. org/10.4322/natcon.2011.006.

Oliveira WL, Scariot A. Boas práticas de manejo para o extrativismo sustentável do pequi. Brasília: Embrapa Recursos Genético e Biotecnologia; 2010. 84 p.

Peres CA, Baider C, Zuidema PA, Wadt LHO, Kainer KA, Gomes-Silva DAP et al. Demographic threats to the sustainability of Brazil nut exploitation. Science 2003; 302(5653): 2112-2114. http://dx.doi.org/10.1126/ science.1091698. PMid:14684819.

Pianovski AR, Vilela AFG, Silva AAAS, Lima CG, Silva KK, Carvalho VFM et al. Uso do óleo de pequi (Caryocar brasiliense) em emulsões cosméticas: desenvolvimento e avaliação da estabilidade física. Revista Brasileira de Ciências Farmacêuticas 2008; 44(2): 250-259. http://dx.doi. org/10.1590/S1516-93322008000200010.

Pinto LCL, Moraes LMO, Guimarães A, Almada ED, Barbosa PMM, Drumond MA. Traditional knowledge and uses of the Caryocar brasiliense Cambess (Pequi) by quilombolas of Minas Gerais, Brazil: subsidies for sustainable management. Brazilian Journal of Biology = Revista Brasileira de Biologia 2016; 76(2): 511-519. http:// dx.doi.org/10.1590/1519-6984.22914. PMid:27058602.

Pozo OVC. O pequi (Caryocar brasiliense): uma alternativa para o desenvolvimento sustentável do cerrado no Norte de Minas Gerais [dissertação]. Lavras: Universidade Federal de Lavras; 1997.

QGIS Development Team. QGIS Geographic Information System. Open Source Geospatial Foundation Project [online]. 2016 [cited $2016 \mathrm{Feb}$ 2]. Available from: http:// www.qgis.org/

Ratter JA, Ribeiro JF, Bridgewater S. The Brazilian cerrado vegetation and threats to its biodiversity. Annali di Botanica 1997; 80(3): 223-230. http://dx.doi.org/10.1006/ anbo.1997.0469.

Rezende ML, Cândido PA. Produção e comercialização de frutos do Cerrado em Minas Gerais. Revista de Política Agrícola 2014; 7(3): 81-86.

Sano SM, Almeida SP, Ribeiro JF. Cerrado: ecologia e flora. Brasília: Embrapa; 2008.

Santana JG, Naves RV. Caracterização de ambientes de Cerrado com alta densidade de pequizeiros (Caryocar brasiliense Camb.) na região sudeste do estado de Goiás. Pesquisa Agropecuária Tropical 2003; 33(1): 1-10.

Schreckenberg K, Degrande A, Mbosso C, Baboule $\mathrm{ZB}$, Boyd C, Enyong L et al. The social and economic importance of Dacryodes edulis (G.Don) H.J. Lam in southern Cameroon. Forests, Trees and Livelihoods 2002; 12(1-2): 15-40. http://dx.doi.org/10.1080/14728028.200 2.9752408 . 
Sinha A, Bawa KS. Harvesting techiques, hemiparasites and fruit production in two non-timber forest tree species in south índia. Forest Ecology and Management 2002; 168(1-3): 289-300. http://dx.doi.org/10.1016/S03781127(01)00747-2.

Soldati GT, Albuquerque UP. Non-Timber Forest Products: an overview. Functional Ecosystems and Communities 2008; $2: 21-31$.

Ticktin T. The ecological implications of harvesting non-timber forest products. Journal of Applied Ecology 2004; 41(1): 11-21. http://dx.doi.org/10.1111/j.13652664.2004.00859.x.

Virillo CB, Martins FR, Tamashiro JY, Santos FAM. Is size structure a good measure of future trends of plant populations? An empirical approach using five woody species from the Cerrado (Brazilian savanna). Acta Botanica Brasílica 2011; 25(3): 593-600. http://dx.doi. org/10.1590/S0102-33062011000300012.

Williams BK. Adaptive management of natural resources framework and issues. Journal of Environmental Management 2011; 92(5): 1346-1353. http://dx.doi.org/10.1016/j. jenvman.2010.10.041. PMid:21075505.

Young CEF, Medeiros R, Queiroz J, Pereira GS. Extrativismo vegetal de produtos não madeireiros no Brasil. Brasília. Ministério do Meio Ambiente; 2012.

Zardo RN, Henriques RPB. Growth and fruit production of the tree Caryocar brasiliense in the Cerrado of central Brazil. Agroforestry Systems 2011; 82(1): 15-23. http:// dx.doi.org/10.1007/s10457-011-9380-9. 